|Fenomena Tari Tayub

\title{
FENOMENA TARI TAYUB DI KECAMATAN JATIROGO KABUPATEN TUBAN
}

\author{
Arim Syahroni ${ }^{1}$ dinamika
}

\begin{abstract}
Tayub is a traditional dance popularized in Kecamatan Jatirogo, Kabupaten Tuban. Tayub dance usually performed in the wedding party, circumcision, and bersih desa which aim to get the fertility. This tayub dance performance is closely related to the social divergence, social labeling, and the effect which is emerged. This study aim to describe the factors considered that tayub is divergent from the public norm which causes social labeling and influences the existence on the profession of ledhek and the effect of tayub dance performance either to ledhek or community in Kecamatan Jatigoro, Kabupaten Tuban

This study is a qualitative descriptive which the primary data resource consisted of ledhek, pengibing, and public figure. The secondary data resource was collected by using documentation and references. The data were collected by: observation, interview, and documentation. The sampling technique used was the purposive sampling. The validity of data used the triangulation and method. In addition, the data analysis consists of several steps, such as data collection, data reduction, presenting data, and conclusion.

This study showed that tayub dance is performed in two sessions; in the midday and night. Tayub and ledhek still exist at the time. It has been shown that the Tuban local government in every year invites the ledhek to be a representative dancer of East Java simultaneously to intend the Culture program in Jakarta, even performs in TMII. In addition, it has been a fundamental program of the Tuban celebration.

Tayub dance performed in the wedding party, circumcision, and purified village ritual are believed to be able to influence the fertility. Tayub dance has a manifest and a laten functions. The manifest function can be considered from its purpose that is gratitude, and keep the good relationship between the figure and its community. The latent function considered from the public divergence, labeling and the effect of tayub dance. The effects of its divergence are sawer (has not been allowed by Tuban government since 2003), drinking alcohol, conflict, and an affair. This social divergence emerges the social labeling on ledhek either positive or negative. Tayub dance has a positive and negative effect to either ledhek or its community. The positive effect can be considered from the high financial reached by the ledhek. Ledhek has an experience performed in Jakarta. On the other hand, the negative effect emerges the negative labeling from the public.
\end{abstract}

Keywords: Tayub, ledhek, social divergence, labeling, effect

\footnotetext{
${ }^{1}$ Alumni Pendidikan Sosiologi FIS UNY
} 


\section{A. Pendahuluan}

Indonesia merupakan negara yang kaya akan budaya, di dalamnya terdapat berbagai bentuk jenis budaya yang dapat dijadikan sebagai ciri khas setiap daerah. Corak ragam budaya seperti tarian tradisional dapat menjadi daya tarik tiap daerah untuk warga setempat. Tarian tradisional yang dimiliki setiap daerah mempunyai perbedaan baik nama maupun gerakannya yang di dalamnya mengandung makna tertentu. Tari tradisional ini merupakan bagian dari seni yang tidak akan terpisahkan dari kehidupan manusia

Seni merupakan salah satu hasil karya manusia yang mempunyai nilai kreativitas tinggi dan sering mengalami perubahan seiring berkembangnya zaman. Salah satunya adalah seni tari yang dalam beberapa kegiatan sering menjadi bagian di dalamnya, baik itu dalam upacara-upacara adat tertentu maupun pagelaran seni yang sifatnya menghibur. Seni tari sebagai ekspresi manusia yang bersifat estetis, kehadirannya tidak bersifat independen atau berdiri sendiri. Dilihat secara tekstual, tari dapat dipahami dari bentuk dan teknik yang berkaitan dengan komposisinya (analisis bentuk atau penataan koreografi) atau teknik penarinya (analisis cara melakukan atau keterampilan). Sementara dilihat secara kontekstual yang berhubungan dengan ilmu sosiologi dan antropologi, tari adalah bagian immanent dan integral dari dinamika sosiokultural

masyarakat.

(Sumandiyo, 2007: 12-13)

Keberadaan seni tari dengan lingkungannya merupakan masalah sosial yang cukup menarik. Beberapa tarian tradisional tertentu saja yang dapat mengemuka dan dapat dinikmati oleh masyarakat. Hal tersebut dikarenakan tarian tradisional masih eksis dilingkungannya. Artinya masyarakat masih menerima dan melestarikan keberadaan tarian tradisional tersebut.

Tayub adalah salah satu jenis tari tradisional yang keberadaannya masih eksis di Jawa Tengah dan Jawa Timur. Tayub sendiri pernah mengalami proses perubahan atau perkembangan sesuai dengan tuntutan peradaban masyarakat. Tayub merupakan seni tari yang diadakan sebagai ungkapan syukur atas rejeki yang diberikan Tuhan. Artinya tayub diadakan dalam rangkaian tradisi upacara bersih desa di lingkungan masyarakat pedesaan yang merupakan ritus kesuburan, yang diharapkan dapat mempengaruhi kesuburan tanah pertanian. (Sumandiyo, 2007: 12-13)

Pelembagaan tari tayub masih berfungsi sebagai pelembagaan ritual khususnya di lingkungan pedesaan Jawa, terutama berfungsi untuk kesuburan tanah pertanian. Tari tayub ini masih sering dilakukan baik menjelang panen raya atau sesudahnya yang sering dikaitkan dengan upacara bersih desa. Tari tayub diselenggarakan pada saat atau setelah panen yang biasanya bertempat di pinggir sawah. Selain 
sebagai rasa syukur karena panennya berhasil, juga memohon keberhasilan selanjutnya. Pelembagaan simbolis itu diwujudkan dalam hubungan antara penari wanita dan penari laki-laki. Penari tayub disebut dengan ledhek ${ }^{2}$ dan penonton lakilaki yang ikut menari disebut pengibing ${ }^{3}$.

Tari tayub juga dipentaskan dalam upacara perkawinan yang secara simbolis mempunyai harapan dapat mempengaruhi kesuburan kedua mempelai. Biasanya mempelai pria mendapat kesempatan pertama mengibing atau menari bersama ledhek. Tarian tayub yang diselenggarakan pada upacara bersih desa maupun upacara perkawinan pada dasarnya mengandung maksud yang sama. Artinya bahwa pengantin perempuan mendapat kesuburan sehingga cepat mendapatkan keturunan.

Tayub merupakan bentuk kesenian rakyat yang sangat digemari di wilayah Kabupaten Tuban khususnya Kecamatan Jatirogo. Penggemar tari tayub ini, terutama pada kalangan masyarakat kelas menengah ke bawah, yang terdiri dari pensiunan, pegawai negeri dan swasta, petani serta masyarakat awam. Pertunjukan tari

${ }^{2}$ Ledhek adalah seorang penari yang menjatuhkan sampurnya pada seorang tamu atau pada umumnya yang harus melayani berbagai lelaki pengibing sehingga mereka harus bersikap ramah, selalu memikat, menggiurkan baik dalam arti tata riasnya, alunan syair-syairnya ataupun gerak tarinya.

3 Pengibing adalah penari pria yang berjoget dengan ledhek. tayub sendiri terbagi dalam dua sesi yaitu siang dan malam. Pada siang hari dimulai sekitar pukul 12.30 WIB hingga pukul 17.00 WIB dan pada malam hari dimulai dari pukul 23.00 WIB hingga pukul 03.30 WIB.

Pertunjukan tari tayub tidak terlepas dari ledhek dan pengibing. Dalam pertunjukan tari tayub, muncul berbagai interaksi baik antara ledhek dengan pengibing, ledhek dengan tokoh masyarakat, ledhek dengan penonton dan berbagai interaksi lainnya yang terjadi dalam pentas tari tayub. Berbagai interaksionisme simbolik tersebut memungkinkan terjadinya penyimpangan terutama ketika pentas tari tayub dimulai. Pengibing yang menunggu pentas tari tayub ini, bisa saja melakukan tindakan yang melanggar norma yang berlaku dalam masyarakat. Seperti melakukan sawer dan lainnya. Minuman keras yang disuguhkan dalam pentas tari tayub juga memungkinkan memicu terjadinya penyimpangan sosial ketika pentas tari tayub berlangsung.

Penyimpangan sosial ketika pentas tari tayub ini mengakibatkan munculnya labeling masyarakat terhadap profesi ledhek baik positif maupun negatif. Labeling merupakan penilaian atau cap oleh masyarakat kepada individu yang melakukan penyimpangan sosial baik itu penyimpangan primer maupun sekunder. Labeling yang diberikan masyarakat merupakan bentuk kontrol sosial bagi mereka yang melanggar nilai dan norma sesuai dengan kebudayaannya masing-masing. Akan tetapi, labeling yang diberikan masyarakat 
terkadang justru menghasilkan sebaliknya seperti yang terjadi pada ledhek. Apalagi jika penyimpangan yang dilakukan berkaitan dengan pelanggaran nilai dan norma masyarakat dimana masih memegang teguh tradisi yang berlaku.

Menjadi seorang ledhek, tidak memerlukan pendidikan formal atau kursus untuk melaksanakan profesi tersebut. Biasanya calon ledhek akan belajar kepada ledhek senior yang sudah terkenal di masyarakat. Profesi ledhek merupakan profesi yang paling rentan terhadap label negatif dari suatu lingkungan masyarakat dan dapat menjadi label yang sulit dihilangkan. Labeling ini muncul bisa dari berbagai faktor baik dari ledhek sendiri atau dari pengibing dan faktor lainnya. Berprofesi sebagai ledhek sangat menjanjikan dengan upah yang cukup besar, akan tetapi hal tersebut tidak bisa menghilangkan label atau cap yang telah diberikan masyarakat, baik itu cap positif maupun negatif.

Label atau cap yang sering diterima ledhek adalah cap negatif dari masyarakat. Hal tersebut dikarenakan adanya anggapan masyarakat bahwa berprofesi sebagai ledhek disamakan dengan pelacur yang identik perusak rumah tangga orang dengan menjadi istri simpanan. Keyakinan akan label negatif yang diberikan masyarakat terhadap ledhek tersebut terlalu dilebih-lebihkan tanpa melihat atau menelusuri bagaimana profesi ledhek sebenarnya. Label atau cap yang diberikan masyarakat ini sebenarnya merupakan upaya kontrol sosial. Akan tetapi, melalui pemberian label pada pelaku penyimpangan seringkali menimbulkan serangkaian peristiwa yang justru mempertegas dan meningkatkan tindak penyimpangan.

Pemberian label terhadap profesi ledhek yang cenderung negatif tidak membuat para ledhek enggan untuk menjalankan profesinya. Hal tersebut dapat dilihat dari berbagai pentas tari tayub yang sering diadakan diacara pernikahan, khitanan, syukuran bersih desa maupun acara lainnya. Citra ledhek yang cenderung negatif tidak membuat para ledhek beralih profesi, justru mereka memilih untuk tetap eksis. Berdasarkan uraian singkat tersebut, maka penulis akan meneliti mengenai fenomena tari tayub di Kecamatan Jatirogo Kabupaten Tuban.

Hal yang menjadi permasalahan kajian ini adalah: Faktor apa sajakah yang melatarbelakangi pentas tari tayub dinilai menyimpang dari norma masyarakat sehingga menimbulkan labeling terhadap profesi ledhek dan mempengaruhi eksistensi ledhek di Kecamatan Jatirogo, Kabupaten Tuban; Bagaimana dampak pentas tari tayub bagi ledhek dan masyarakat di Kecamatan Jatirogo, Kabupaten Tuban

\section{B. Rangkaian Pentas Tari Tayub}

Tayub merupakan kesenian yang menonjol di Kabupaten Tuban. 
Hal tersebut dapat dilihat dari pentas tari tayub yang sering dilakukan di Kabupaten Tuban khususnya di Kecamatan Jatirogo. Tari tayub dalam pelaksanaannya terbagi menjadi dua sesi yaitu siang dan malam. Pada siang hari dimulai sekitar pukul 12.30 WIB hingga pukul 17.00 WIB dan pada malam hari dimulai dari pukul 23.00 WIB hingga pukul 03.30 WIB. Jadwal pelaksanaan pentas tari tayub ini merupakan aturan dari Pemerintah Kabupaten Tuban yaitu Dinas Kebudayaan dan Pariwisata. Selain itu, sebelum diadakan pentas tari tayub pihak yang mempunyai hajat harus mengurus ijin pentas di Dinas Kebudayaan dan Pariwisata setempat yang nantinya akan dibantu oleh ledhek yang akan ditanggap besok ketika pentas. Hal ini bertujuan agar pentas tari tayub berjalan dengan lancar dan aman. Tari tayub dalam pelaksanaannya harus melalui beberapa rangkaian yang sudah menjadi aturan turun-temurun dari dahulu. Rangkaian pentas tari tayub tersebut antara lain:

\section{Pembukaan}

Pembukaan

merupakan

rangkaian pertama dalam pentas tari tayub, yang mana dilakukan oleh pengarih. Pembukaan di sini meliputi salam pembuka, ucapan selamat datang kepada para tokoh masyarakat dan tamu undangan. Selain itu, pengarih juga menyampaikan ucapan terima kasih atas kehadiran dari semua pihak yang telah hadir pada pentas tari tayub.

2. Tari gambyong
Maksud dari tari gambyong adalah untuk menyambut para tamu yang sudah hadir dalam pentas tari tayub atau sebagai tari penyambutan. Tari gambyong ini hanya dilakukan pada malam hari saja, karena acara malam merupakan acara inti yang mana ada penyampaian maksud diadakannya pentas tari tayub.

3. Penyampaian maksud diadakannya pentas tari tayub

Penyampaian maksud di sini dilakukan oleh pengarih. Misalnya jika dalam acara pernikahan, khitanan sedekah bumi dan sebagainya, maka pengarih harus menyampaikan maksud tuan rumah tersebut dengan jelas dan benar. Kemudian setelah penyampaian maksud diadakannya pentas tari tayub, pengarih akan memperkenalkan semua pihak atau unsur-unsur yang ada dalam pentas tari tayub.

4. Acara inti (pentas tari tayub) Acara inti dimulai dengan duduknya tuan rumah di tengahtengah ledhek sambil mendengarkan gendhing yang dinyanyikan atau dilantunkan oleh ledhek. Kemudian tuan rumah memberikan uang tanggapan tetapi hanya formalitas yaitu hanya 50\% dari bayaran ledhek dan itu pun diberikan dengan cara sopan yaitu lewat tangan bukan sawer. Sebagai tanda kehormatan, tuan rumah yang punya hajat mendapatkan kesempatan pertama kali untuk ngibing bersama ledhek. Setelah tuan rumah ngibing, kesempatan berikutnya diberikan kepada para tokoh masyarakat seperti perwakilan kecamatan, 
jajaran kepolisian, koramil, kepala desa, tamu undangan, teman terdekat tuan rumah dan masyarakat luas.

\section{Penutup}

Penutup di sini berisi tentang ucapan terima kasih kepada tuan rumah, tokoh masyarakat dan tamu undangan yang telah berperan dalam pentas tari tayub.

\section{Eksistensi Ledhek di Kecamatan Jatirogo Kabupaten Tuban}

Pentas tari tayub sering diselenggarakan di Kecamatan Jatirogo. Hal ini dikarenakan jumlah ledhek yang ada di Kecamatan Jatirogo cukup banyak. Selain itu, masyarakat di Kecamatan Jatirogo juga masih antusias dan menyukai keberadaan tari tayub itu sendiri. Keberadaan tari tayub di Kecamatan Jatirogo masih eksis sampai sekarang. Eksistensi tersebut tidak terlepas dari unsur-unsur yang ada dalam tari tayub itu sendiri. Ledhek Pengibing, pengarih, pengrawit merupakan unsur penting dalam pentas tari tayub di mana mereka memberikan pengaruh besar terhadap eksistensi tari tayub.

Ledhek merupakan salah satu unsur penting dalam pentas tari tayub selalu dituntut untuk dapat mengikuti perkembangan zaman. Perkembangan tersebut dapat dilihat dari gendhing-gendhing yang dilantunkan atau dinyanyikan. Ketika pentas tari tayub tidak hanya gendhing Jawa atau tradisional saja yang dinyanyikan oleh ledhek akan tetapi juga lagu-lagu pop, dangdut yang baru digemari masyarakat. Lagu-lagu tersebut seperti keong racun, cinta satu malam, bang toyib, cari jodoh dan lain sebagainya. Kemudian lagu-lagu tersebut dikolaborasikan dengan gamelan agar para pengibing lebih terhibur. Perkembangan tari tayub yang lain dapat dilihat dari segi ledheknya sendiri dituntut untuk selalu berpenampilan menarik ketika pentas dengan cara menggunakan baju yang berbeda dengan baju yang digunakan dalam pentas tari tayub sebelumnya. Intinya bahwa dari segi kualitas ledhek harus ditingkatkan, baik dari segi suara maupun segi penampilan.

Perkembangan yang menuntut kualitas ledhek untuk menjadi lebih baik juga disertai dengan naiknya upah ledhek ketika pentas. Pada tahun 1990-an upah ledhek yang sudah senior masih berkisar antara Rp. 500.000,- sampai dengan Rp 700.000,-. Sedangkan sekarang untuk ledhek senior upahnya ketika pentas mencapai Rp. 3.000.000,- sampai dengan Rp. 3.500.000,-. Upah tersebut pun kalau pentasnya masih dalam satu wilayah. Kalau beda wilayah upahnya bisa lebih besar karena ada tambahan uang transportasi dan sebagainya. Upah ledhek satu dengan lainnya berbeda-beda. Hal tersebut sesuai dengan kelas-kelas yang sudah terbentuk dalam dunia ledhek. Ledhek kelas atas sekali pentas mendapatkan upah sebesar Rp. 3.000.000,- sampai dengan Rp. 3.500.000,- kelas menengah, sekali pentas Rp. 2.000.000,- sampai 
dengan Rp. 3.000.000,- sedangkan untuk kelas biasa, sekali pentas ledhek mendapatkan upah sebesar Rp. 1.500.000,- sampai dengan Rp. 2.000.000,-. Pembagian kelas-kelas ledhek tersebut berdasarkan senioritas ledhek. Semakin senior seorang ledhek dengan jam terbang yang tinggi maka ledhek tersebut akan semakin terkenal di masyarakat. Tinggi dan rendah tidaknya jam terbang ledhek tersebut berdasarkan kriteria, yaitu kualitas vokal atau suara ledhek yang bagus dan penampilannya yang selalu menarik ketika pentas.

Selama ini eksistensi ledhek memang masih terlihat di masyarakat. Setiap tahunnya Kabupaten Tuban selalu mengirimkan ledhek untuk menjadi salah satu perwakilan Provinsi Jawa Timur untuk mengikuti Anjungan Budaya di Jakarta melalui tari tayub. Tari tayub dari Kabupaten Tuban juga sering tampil di Taman Mini Indonesia Indah (TMII) dalam festival budaya daerah yang ada di Indonesia. Tayub juga merupakan salah satu acara wajib dan tidak pernah ketinggalan untuk menjadi salah satu bagian yang ikut meramaikan hari Jadi Kabupaten Tuban. Sebelum para ledhek tampil dalam hari jadi Kabupaten Tuban, mereka harus mengikuti kirab yang dilakukan oleh Dinas Kebudayaan dan Pariwisata. Kirab tersebut dilakukan setiap satu tahun sekali yaitu tiga bulan sebelum hari jadi Kabupaten Tuban. Pelaksanaan kirab tesebut dilakukan di Sendang Bektiharjo Kecamatan Semanding Kabupaten Tuban. Peserta yang ikut dalam kirab tersebut antara lain meliputi ledhek, pemimpin adat atau sesepuh, dan pengarih.

Selain Anjungan Budaya di Jakarta, festival di TMII, dan acara wajib ketika hari jadi Kabupaten Tuban, pentas tari tayub juga sering diselenggarakan dalam acara hajatan seperti khitanan, pernikahan dan tradisi sedekah bumi. Masyarakat yang sering menyelenggarakan pentas tari tayub untuk khitanan, pernikahan dan sedekah bumi (setelah panen padi) adalah masyarakat yang tinggal di Kecamatan Jatirogo. Data tersebut dapat dilihat dari jadwal pentas tari tayub di Kecamatan Jatirogo dalam setahun terakhir, terhitung mulai bulan Januari-Juli 2010 terdapat 18 kali pementasan tari tayub. Data pementasan tersebut adalah sebagai berikut:

Berdasarkan data jadwal pentas tari tayu, maka dapat dilihat bahwa ledhek yang ada di Kecamatan Jatirogo masih eksis. Eksistensi ledhek tersebut dipengaruhi oleh beberapa faktor antara lain:

\section{Faktor internal}

Faktor internal merupakan faktor yang muncul dari dalam diri ledhek sendiri. Selama ini ledhek tetap memilih atau bertahan menjalankan profesinya sebagai ledhek karena mereka sudah terlanjur senang dan nyaman dengan profesinya tersebut. Apalagi dari segi materi yang mereka peroleh ketika pentas tari tayub cukup besar. Setiap satu kali pentas, ledhek dapat memperoleh upah rata-rata Rp. 3.000.000,-. Misal dalam satu bulan ada 4 kali pentas berarti ledhek tersebut mendapatkan Rp. 12.000.000,- Alasan lain yang 
|Fenomena Tari Tayub

membuat ledhek tetap menjalankan profesinya karena mereka memang menyukai seni. Dari kecil ledhek tersebut sudah dikenalkan taritarian melalui paguyuban atau ketoprak yang mengasah bakat mereka.

2. Faktor eksternal

Faktor eksternal di sini lebih mengarah pada tanggapan atau respon dari masyarakat yang menerima tari tayub untuk tetap dapat pentas. Selain itu, melihat perkembangan yang ada, pemerintah Kabupaten Tuban semakin memberikan perhatian khusus terhadap tari tayub terutama ledhek. Hal tersebut dapat dilihat dari diadakannya sekolah yang ditujukan untuk para ledhek dengan tujuan peningkatan kualitas dan monitoring keaktifan para ledhek yang ada di Kabupaten Tuban. Sekolah ledhek tersebut berada di bawah naungan Dinas Kebudayaan dan Pariwisata Kabupaten Tuban. Jadwal sekolahnya dilaksanakan pada hari Rabu dan Sabtu pukul 13.00-15.00 WIB.

\section{Penyimpangan dan Labeling Terhadap Tari Tayub di Kecamatan Jatirogo Kabupaten Tuban}

Tari tayub dalam perkembangannya tidak terlepas dari penyimpangan sosial dan labeling yang diberikan masyarakat. Bentuk-bentuk penyimpangan yang terjadi pun bermacam-macam. Begitu juga dengan labeling yang diberikan masyarakat terhadap ledhek. Ada labeling yang positif dan ada labeling negatif. Tergantung dari sudut pandang mana masyarakat memberikan label tersebut. Bentuk-bentuk penyimpangan dalam pentas tari tayub dan faktor-faktor labeling terhadap ledhek adalah sebagai berikut:

\section{Bentuk-bentuk \\ Penyimpangan yang \\ Terjadi dalam Pentas Tari Tayub}

Penyimpangan merupakan salah satu bentuk tindakan individu atau kelompok yang tidak sesuai dengan nilai dan norma yang berlaku dalam masyarakat tertentu. Penyimpangan dapat terjadi di mana pun dan kapan pun tanpa mengenal waktu dan tempat. Penyimpangan dapat dilakukan oleh siapa saja termasuk masyarakat biasa dan tokoh masyarakat, meskipun tingkat penyimpangan yang dilakukan tiap individu tersebut berbeda-beda. Penyimpangan dapat terjadi tidak hanya di lokasi yang memang menjadi tempat terjadinya penyimpangan, akan tetapi di tempat biasa pun dapat terjadi penyimpangan. Apalagi kalau dalam tempat tersebut ada acara tertentu yang sifatnya menghibur, menghadirkan dan melibatkan orang banyak dari berbagai kalangan.

Pentas tari tayub merupakan salah satu acara yang melibatkan banyak orang dari berbagai kalangan, baik dari kalangan atas, menegah maupun bawah. Dalam 
pelaksanaannya terjadi berbagai interaksi baik antara ledhek dengan pengibing, ledhek dengan tokoh masyarakat, ledhek dengan penonton dan berbagai interaksi lainnya yang terjadi dalam pentas tari tayub.

Berbagai interaksi yang terjadi dalam pentas tari tayub dapat menimbulkan penyimpangan sosial. Penyimpangan tersebut seperti pengibing yang menunggu pentas tari tayub ini, bisa saja melakukan tindakan yang melanggar norma yang berlaku dalam masyarakat. Seperti melakukan sawer, minum-minuman keras dan konflik antar pengibing. Minuman keras yang disuguhkan dalam pentas tari tayub di sini juga menjadi faktor pemicu terjadinya penyimpangan sosial ketika pentas tari tayub berlangsung.

Bentuk penyimpangan sosial seperti sawer pada tahun 2003 sudah mulai dilarang oleh pemerintah Kabupaten Tuban. Jadi sekarang untuk menemukan pengibing yang nyawer dalam pentas tari tayub sudah jarang bahkan hampir tidak ada. Akan tetapi, dalam pentas tari tayub masih ada pengibing yang secara lisan berusaha menggoda ledhek, dan minta dituangkan bir ke dalam gelas sebelum pengibing tersebut meminumnya.

Bentuk penyimpangan lain yang masih terlihat dalam pentas tari tayub adalah minum-minuman keras, mabuk-mabukan dan konflik. Minum-minuman keras menjadi salah satu bagian yang belum dapat dipisahkan dari pentas tari tayub untuk saat ini. Hal ini dikarenakan dari kalangan pemerintah sendiri kurang tegas dalam menyikapinya.
Selain itu, tokoh masyarakat yang harusnya memberikan contoh yang baik untuk rakyatnya juga ikut mabuk-mabukan dalam pentas tari tayub. Berdasarkan hasil wawancara diperoleh data bahwa setiap pentas tari tayub pengibing dapat menghabiskan lima botol bir.

Pemerintah hanya melarang pengarih saja yang tidak boleh minum-minuman keras. Hal tersebut bertujuan agar pengarih tetap menjalankan perannya secara adil dalam menentukan siapa tamu undangan yang mempunyai kesempatan untuk ngibing terlebih dahulu. Pengarih di sini juga harus lincah mengatur acara, jika waktu pentas tari tayub sudah hampir habis, akan tetapi, tamu masih banyak maka selendang atau sampur untuk pengibing diperbanyak agar tamu bisa ngibing semua. Kalau para tamu tidak bisa ngibing semua akan timbul konflik apalagi para tamu sudah minumminuman keras yang membuat para pengibing mudah untuk terpancing emosi. Meskipun pemerintah sudah melarang pengarih untuk tidak ikut minum-minuman keras akan tetapi masih ada pengarih yang melanggarnya.

Bentuk penyimpangan selain minum-minuman keras yaitu konflik yang terjadi antara pengarih dengan pengibing dan pengibing satu dengan pengibing lainnya. Konflik antara pengarih dan pengibing sering terjadi. Biasanya pengibing marahmarah emosi kepada pengarih jika mereka lama mendapat giliran ngibing. Konflik selanjutnya yaitu konflik antar pengibing. Konflik tersebut dapat terjadi karena 
mereka saling berbicara negelantur hingga akhirnya terjadi kesalahpahaman. Pembicaraan yang ngelantur tersebut dipicu oleh minum-minuman keras yang berlebihan sehingga mereka saling emosi dan tidak terkendali. Selain itu, konflik yang biasa terjadi adalah cek-cok antar pengibing hingga ujung-ujungnya terjadi pemukulan dalam pentas tari tayub.

Penyimpangan yang terjadi selain minum-minuman keras dan konflik adalah, adanya tokoh masyarakat yang selingkuh dengan ledhek disela-sela waktu istirahat pentas tari tayub. Seperti ada tokoh masyarakat yang bermesraan $\mathrm{di}$ kamar ganti para ledhek. Tokoh masyarakat tersebut adalah pihak kepolisian dan koramil.

Berdasarkan jenis perilaku menyimpang, maka perilaku menyimpang dalam pentas tari tayub termasuk dalam tindakan yang nonconform, yaitu perilaku yang tidak sesuai dengan nilai-nilai atau norma-norma yang ada. Ada beberapa orang yang menyatakan bahwa perilaku menyimpang adalah ketika orang lain melihat perilaku itu sebagai sesuatu yang berbeda dari kebiasaan masyarakat pada umumnya. Terjadinya perilaku meyimpang (nonconform) dipastikan selalu ada dalam kehidupan masyarakat. Termasuk dalam pentas tari tayub perilaku menyimpang juga pasti ada, seperti minum-minuman keras, konflik antar pengibing, konflik antara pengarih dan pengibing, dan perselingkuhan antara ledhek dengan tokoh masyarakat yang ikut ngibing.

Berdasarkan empat sudut pandang tersebut, maka penyimpangan sosial yang terjadi dalam pentas tari tayub termasuk dalam perilaku menyimpang reaktif dan normatif. Perilaku menyimpang reaktif merupakan hasil sudut pandang kaum reaktivitas berkenaan dengan reaksi masyarakat atau agen kontrol sosial terhadap tindakan yang dilakukan seseorang. Artinya, apabila ada reaksi dari masyarakat atau agen kontrol sosial dan kemudian mereka memberi cap atau tanda (labeling terhadap si pelaku, maka perilaku itu telah dicap menyimpang). Sedangkan perilaku menyimpang normatif, menyatakan bahwa penyimpangan adalah suatu pelanggaran dari suatu norma. Perilaku menyimpang reaktif dan normatif memang tepat untuk menganalisis penyimpangan yang terjadi dalam pentas tari tayub, karena tindakan yang dilakukan para pengibing telah melanggar norma yang berlaku dalam masyarakat dan mendapat cap atau labeling menyimpang dari masyarakat.

Berdasarkan jenis deviasi menurut fungsinya, maka perilaku menyimpang yang terjadi dalam pentas tari tayub termasuk dalam deviasi situasional. Deviasi situasional di sini dapat dilihat pada bagaimana para pengibing melakukan tindakan atau perilaku menyimpang karena adanya pengaruh situasional yaitu situasi 
pentas tari tayub yang menjadi bagian yang integral dalam dirinya. Situasi dalam pentas tari tayub dinilai dapat menjadi faktor pendukung dalam melakukan tindakan menyimpang.

Perilaku menyimpang yang terjadi dalam pentas tari tayub tersebut berawal dari interaksionisme simbolik dari unsur-unsur dalam pentas tari tayub seperti, ledhek, pengibing, pengarih dan lainnya. Mereka dalam interaksinya menafsirkan berbagai simbol-simbol komunikasi yang mengantarkan mereka untuk berperilaku menyimpang karena tiap individu mempunyai penafsiran yang berbeda-beda. Bentuk-bentuk perilaku menyimpang yang terjadi dalam pentas tari tayub tersebut kemudian termasuk dalam perilaku menyimpang yang nonconform, reaktif, normatif dan situasional.

\section{Faktor-faktor Labeling terhadap Ledhek}

Labeling merupakan

penilaian atau cap dari masyarakat kepada individu yang melakukan penyimpangan sosial baik itu penyimpangan primer maupun sekunder. Labeling yang diberikan masyarakat merupakan bentuk kontrol sosial bagi mereka yang melanggar nilai dan norma sesuai dengan kebudayaannya masingmasing. Contoh labeling yang diberikan masyarakat sebagai bentuk kontrol sosial adalah labeling yang diberikan kepada ledhek. Ledhek sering mendapatkan labeling dari masyarakat, baik itu pisitif maupun negatif. Labeling tersebut diberikan karena adanya berbagai bentuk penyimpangan yang terjadi dalam pentas tari tayub yang mana ledhek berkaitan erat sebagai salah satu unsur di dalamnya.

Penyimpangan sosial seperti sawer, minum-minuman keras, konflik dan perselingkuhan ketika pentas tari tayub ini mengakibatkan munculnya labeling masyarakat terhadap profesi ledhek baik positif maupun negatif. Labeling positif diberikan kepada ledhek karena secara tidak langsung ledhek telah berperan dalam mengembangkan tari tayub hingga menjadi salah satu kebudayaan yang diunggulkan oleh Pemerintah Kabupaten Tuban. Tayub juga menjadi salah satu kebudayaan yang tiap tahunnya mewakili Jawa Timur untuk mengikuti anjungan budaya ke Jakarta.

Selain labeling positif, masyarakat juga memberikan labeling negatif kepada ledhek. Labeling negatif tersebut diberikan karena ada beberapa faktor yang melatarbelakanginya. Faktor tersebut antara lain:

a. Adanya sawer yang dilakukan pengibing dalam pentas tari tayub. Yaitu memasukkan uang ke dalam kemben atau di sela-sela payudara ledhek., sehingga masyarakat luas yang menonton pentas tari tayub memberikan lebeling negatif kepada ledhek.

b. Adanya minum-minuman keras dalam pentas tari tayub yang membuat para pengibing mabuk-mabukkan. 
Fenomena Tari Tayub

c. Adanya konflik atau perkelahian antara pengibing di arena pentas tari tayub.

d. Ledhek merangkap sebagai wanita tuna susila atau istri simpanan. Istilah menjadi istri simpanan atau penjual diri yang dilekatkan pada diri ledhek sudah tidak asing lagi di telinga masyarakat. Memang tidak semua ledhek menjadi istri simpanan, akan tetapi masyarakat umum telah mengeneralisir itu semua sehingga memberikan labeling negatif kepada semua ledhek.

Interaksi antara ledhek dengan pengibing dan penyimpangan yang terjadi dalam pentas tari tayub menimbulkan konsekuensi-konsekuensi sendiri di mana konsekuensi tersebut berupa labeling negatif yang diberikan oleh masyarakat. Labeling tersebut diberikan karena adanya reaksi masyarakat setelah melihat berbagai penyimpangan yang terjadi dalam pentas tari tayub. Labeling yang diberikan sebenarnya adalah sebagai bentuk kontrol sosial terhadap perilaku menyimpang yang terjadi dalam pentas tari tayub.

Masyarakat sebagai agen kontrol sosial memang mempunyai peran penting untuk membantu dalam mengendalikan perilaku menyimpang yang terjadi dalam masyarakat. Adanya labeling dari masyarakat yang ditujukan kepada ledhek menjadi bukti bahwa kontrol sosial masyarakat masih berperan.
Akan tetapi labeling yang diberikan tersebut justru membuat individu atau pelaku penyimpangan bertindak untuk selalu melanggar norma yang berlaku dalam masyarakat tersebut. Misalnya dalam pentas tari tayub, masih tetap ada minum-minuman keras oleh pengibing. Ledhek masih mau menuangkan bir ke dalam gelas para pengibing, masih ada konflik dan masih ada perselingkuhan di balik pentas tari tayub. Oleh karena itu, labeling negatif dari masyarakat terhadap ledhek sendiri susah untuk dihilangkan.

\section{E. Dampak Pentas Tari Tayub di Kecamatan Jatirogo Kabupaten Tuban}

Setiap kegiatan atau tindakan yang dilakukan individu maupun kelompok pasti menimbulkan dampak. Baik itu berdampak untuk diri individu, kelompok maupun masyarakat luas. Dampak tersebut juga dapat bernilai positif dan negatif. Begitu juga dengan adanya pentas tari tayub menimbulkan dampak positif dan negatif bagi individu (ledhek) dan masyarakat. Berikut adalah penjelasan dampak pentas tari tayub di Kecamatan Jatirogo:

\section{Dampak terhadap individu (ledhek)}

Pentas tari tayub mempunyai dampak terhadap individu yaitu ledhek. Dampak tersebut dapat positif dan negatif. Dampak positif dapat dilihat dari segi materi yang diperoleh ledhek cukup besar. Jika dalam satu bulan ledhek tersebut 
mendapat kesempatan 4 kali pentas tari tayub maka, penghasilan yang diperoleh sebesar Rp. 12.000.000. Padahal bisa saja dalam satu bulan itu ledhek 8 sampai 10 kali pentas. Jadi penghasilan ledhek dapat dibilang besar. Selain itu, dampak positif yang dirasakan ledhek adalah mempunyai pengalaman pentas di Jakarta sebagai perwakilan Jawa Timur dalam anjungan budaya Indonesia. Ledhek juga semakin terkenal di masyarakat luas terutama sesama pelaku seni. Ledhek di sini merasa bahwa eksistensinya selama ini dihargai karena dapat membawa nama Kabupaten Tuban di tingkat nasional.

Dampak negatif yang di alami ledhek juga ada, seperti mendapat labeling negatif dari masyarakat. Labeling tersebut seperti ledhek itu sering menjadi istri simpanan, perebut suami orang dan perusak rumah tangga orang. Adanya lebeling negatif dari masyarakat memang membuat ledhek merasa tidak nyaman apalagi bekerja sebagai ledhek adalah pekerjaan yang rentan terhadap label negatif karena kerjanya yang menuntut sehari semalam. Akan tetapi, labeling yang diberikan masyarakat tersebut tidak lantas membuat ledhek meninggalkan pekerjaannya untuk beralih profesi.

\section{Dampak masyarakat}

Dampak pentas tari tayub terhadap masyarakat dapat dilihat dari berbagai sudut pandang baik itu yang positif maupun negatif. Dampak positif dapat dilihat dari segi ekonomi, sosial, dan budaya yang ada dalam masyarakat. Dari segi ekonomi, adanya pentas tari tayub memberikan keuntungan sendiri terhadap masyarakat yang berdagang di arena pentas tari tayub. Adanya pentas tari tayub muncul pasar kecil dadakan yang menjual berbagai jenis makanan, minuman, mainan, dan pernakpernik lainnya yang dapat membantu menambah penghasilan para pedagang yang merupakan masyarakat setempat. Dari segi sosial, dampak positif adanya pentas tari tayub antara lain menjadi salah satu kesempatan untuk bersilaturahmi antara masyarakat satu dengan lainnya. Hal ini dikarenakan dalam pentas tari tayub dihadiri oleh tokoh masyarakat seperti perangkat desa, kecamatan, kepolisian dan koramil serta masyarakat umum yang juga mendapatkan undangan.

Selain dampak positif di atas, ada juga dampak negatif dari segi sosial yaitu penyimpangan yang terjadi dalam pentas tari tayub membuat masyarakat resah karena ada mabuk-mabukan dan konflik yang mana membuat masyarakat tidak nyaman. Dampak positif tari tayub bagi masyarakat jika dilihat dari segi budaya yaitu pentas tari tayub membuat masyarakat tahu bahwa tari tayub merupakan salah satu kebudayaan yang diunggulkan di Kabupaten Tuban. Sehingga masyarakat mempunyai pemikiran dan usaha agar lebih menghargai dan menghormati tari tayub. Walaupun pada kenyataannya setiap pentas tari tayub pasti ada perilaku menyimpang seperti minum-minuman keras dan konflik antar pengibing. Masyarakat paling 
tidak yang selama ini memberikan labeling negatif terhadap tari tayub dan ledhek tidak hanya menilai negatif akan tetapi juga ada segi positifnya.

\section{F. Simpulan}

Berdasarkan penelitian tentang fenomena tari tayub di Kecamatan Jatirogo Kabupaten Tuban maka dapat diambil kesimpulan bahwa tari tayub merupakan salah satu kesenian tradisional yang diunggulkan oleh Pemerintah Kabupaten Tuban. Tari tayub dalam pelaksanaannya harus melalui beberapa rangkaian yaitu: pembukaan, tari gambyong, penyampaian maksud diadakannya pentas tari tayub, acara inti (pentas tari tayub), penutup.

Selain rangkaian pentas tari tayub di atas, eksistensi tari tayub dan ledhek juga masih terlihat. Pemerintah Kabupaten Tuban setiap tahunnya selalu mengirimkan ledhek menjadi salah satu perwakilan Provinsi Jawa Timur untuk mengikuti Anjungan Budaya di Jakarta melalui tari tayub. Tari tayub dari Kabupaten Tuban juga sering tampil di TMII dalam festival budaya daerah yang ada Indonesia. Setiap hari jadi Kabupaten Tuban, tayub juga merupakan salah satu acara wajib dan tidak pernah ketinggalan untuk menjadi salah satu bagian yang ikut meramaikan.

Berdasarkan pemaparan di atas maka dapat disimpulkan bahwa eksistensi ledhek dipengaruhi oleh beberapa faktor antara lain:

1. Faktor internal
Selama ini ledhek tetap memilih atau bertahan menjalankan profesinya sebagai ledhek karen mereka memang menyukai seni. Apalagi dari segi materi yang mereka peroleh ketika pentas tari tayub cukup besar.

\section{Faktor eksternal}

Alasan kenapa ledhek masih mempertahankan eksistensinya yaitu karena masyarakat masih menerima keberadaan tari tayub dan pemerintah Kabupaten Tuban memberikan perhatian khusus untuk meningkatkan kualitas ledhek.

Pentas tari tayub dalam penyelenggaraannya tidak terlepas dari penyimpangan yang dilakukan oleh berbagai pihak dan labeling yang diberikan masyarakat kepada para ledhek serta dampak yang ditimbulkan. Bentuk-bentuk penyimpangan dan labeling masyarakat terhadap ledhek serta dampak yang ditimbulkan adalah sebagai berikut:

1. Bentuk-bentuk penyimpangan yang terjadi dalam pentas tari tayub

Pentas tari tayub dalam pelaksanaannya disertai berbagai bentuk penyimpangan seperti sawer (sejak tahun 2003 dilarang oleh Pemerintah Kabupaten Tuban), minum-minuman keras, mabukmabukan dan konflik serta perselingkuhan. Minum-minuman keras menjadi salah satu bagian yang belum dapat dipisahkan dari pentas tari tayub untuk saat ini. Hal ini dikarenakan dari kalangan pemerintah sendiri kurang tegas dalam menyikapinya. 
Konflik yang terjadi dalam pentas tari tayub biasanya konflik antar pengibing dan konflik antara pengarih dan pengibing. Selain itu, bentuk penyimpangan lainnya yaitu adanya tokoh masyarakat yang selingkuh dengan ledhek disela-sela waktu istirahat pentas tari tayub. Seperti ada tokoh masyarakat yang bermesraan di kamar ganti para ledhek. Tokoh masyarakat tersebut adalah pihak kepolisian dan koramil.

\section{Faktor-faktor Labeling} terhadap Ledhek

Penyimpangan sosial seperti sawer, minum-minuman keras, konflik dan perselingkuhan ketika pentas tari tayub mengakibatkan munculnya labeling masyarakat terhadap profesi ledhek baik positif maupun negatif. Labeling positif diberikan kepada ledhek karena secara tidak langsung ledhek telah berperan dalam mengembangkan tari tayub hingga menjadi salah satu kebudayaan yang diunggulkan oleh Pemerintah Kabupaten Tuban. Sedangkan labeling negatif diberikan kepada ledhek karena ada beberapa faktor yang melatarbelakanginya. yaitu:
a. Adanya sawer yang dilakukan pengibing dalam pentas tari tayub.
b. Adanya minum-minuman keras dalam pentas tari tayub.
c. Adanya konflik antara pengibing dalam pentas tari tayub.
d. Ledhek merangkap sebagai wanita tuna susila atau istri simpanan.
3. Dampak Pentas Tari Tayub
di Kecamatan Jatirogo Kabupaten Tuban

Adanya pentas tari tayub menimbulkan dampak positif dan negatif bagi individu (ledhek) dan masyarakat. Dampak tersebut adalah:
a. Dampak terhadap individu (ledhek)

Pentas tari tayub mempunyai dampak terhadap individu yaitu ledhek. Dampak tersebut dapat positif dan negatif. Dampak positif dapat dilihat dari segi materi yang diperoleh ledhek cukup besar. Jika dalam satu bulan ledhek tersebut mendapat kesempatan 4 kali pentas tari tayub maka, penghasilan yang diperoleh sebesar Rp. 12.000.000,Selain itu dampak positif yang dirasakan ledhek adalah mempunyai pengalaman pentas di Jakarta sebagai perwakilan Jawa Timur dalam anjungan budaya Indonesia.

Dampak negatif yang dialami ledhek juga ada, seperti mendapat labeling negatif dari masyarakat. Labeling tersebut seperti ledhek itu wanita murahan, perebut suami orang, perusak rumah tangga orang dan sebagainya.
b. Dampak terhadap masyarakat
Dampak pentas tari tayub terhadap masyarakat dapat dilihat dari berbagai sudut pandang. Dari segi ekonomi, sosial, dan budaya. Dari segi ekonomi, adanya pentas tari tayub memberikan keuntungan sendiri terhadap masyarakat yang berdagang di arena pentas tari tayub. Adanya pentas tari tayub muncul pasar kecil dadakan yang menjual berbagai jenis makanan, minuman, mainan, dan pernak- 
| Fenomena Tari Tayub

pernik lainnya yang dapat membantu menambah penghasilan para pedagang tersebut.

$$
\text { Dari segi sosial }
$$

penyimpangan yang terjadi dalam pentas tari tayub membuat masyarakat resah karena ada mabuk-mabukan dan konflik membuat masyarakat tidak nyaman. Dampak tari tayub bagi masyarakat jika dilihat dari segi budaya, pentas tari tayub membuat masyarakat tahu bahwa tari tayub merupakan salah satu kebudayaan yang diunggulkan di Kabupaten Tuban. Sehingga masyarakat mempunyai pemikiran dan usaha agar lebih menghargai dan menghormati tari tayub. Walaupun pada kenyataannya setiap pentas tari tayub pasti ada perilaku menyimpang seperti minumminuman keras dan konflik antar pengibing.

\section{Daftar Pustaka}

Bagong Suyanto dan Sutinah. 2006. Metode Penelitian Sosial Berbagai Alternatif Pendekatan. Jakarta: Kencana.

Ben Suharto. 1999. Tayub Pertunjukan dan Ritus Kesuburan. Bandung: Masyarakat Seni Pertunjukan Indonsia Arti.line.

Burhan Bungin. 2008. Penelitian Kualitatif Komunikasi, Ekonomi, Kebijakan Publik, dan Ilmu Sosial Lainnya. Jakarta: Kencana.
Craib Ian. 1992. Teori-Teori Sosial Modern dari Parsons sampai Habermas. Jakarta: Rajawali.

Dandang Ahmad Dahlan. 2005. Tayub Pati dan Ledheknya. Pati: Ciptamedia Binanusa.

J Dwi Narwoko. 2004 . Sosiologi Teks Pengantar dsan Terapan. Jakarta: Kencana.

Hassan Shadily. 1993. Sosiologi Untuk Masyarakat Indonesia. Jakarta: Rineka Cipta.

Henslin M James. 2007. Sosiologi dengan Pendekatan Membumi. Jakarta: Erlangga.

Kartini Kartono. 2007. Patologi Sosial. Jakarta: RajaGrafindo Persada.

Khairuddin. 1992. Sosiologi Keluarga. Yogyakarta: Nur Cahaya.

Koentjaraningrat. 1981. Metodemetode Penelitian Masyarakat. Jakarta: Gramedia.

M Soedarsono. 2002. Seni Pertunjukan Indonesia di Era Globalisasi. Yogyakarta: UGM Press.

Maleong Lexy J. 2005. Metodologi Penelitian Kualitatif. Bandung: Remaja Rosda Karya.

Margaret M Poloma. 2004. Sosiologi Kontemporer. Jakarta: RajaGrafindo. 
Miles dan Huberman. 1992. Analisis Data Kualitatif. Jakarta: Universitas Indonesia Press.

Muhammad Basrowi dan Soenyono. 2004. Memahami Sosiologi. Surabaya: Lutfansah Mediatama.

Norman K Denzin dan Yvonna S Lincoln. 1997. Handbook of Qualitative Research. India: Greater Kailash I New Delhi.

Pemerintah Kabupaten Tuban Kantor Informasi dan Komunikasi. 2002. Selayang Pandang Tuban Triwulan 2. Tuban: Kantor Informasi dan Komunikasi.

-------. 2006. Pemerintahan Kabupaten Tuban Dalam Untaian Sejarah. Tuban: Kantor Informasi dan Komunikasi.

-------. 2009. Monografi Kecamatan Jatirogo Tahun 2009. Tuban: BPS.

Ritzer George, dkk. 2004. Teori Sosiologi dari Sosiologi Klasik Sampai Perkembangan Mutakhir Teori Sosial Postmodern. Yogyakarta: Kreasi Wacana.

-------. 2007. Teori Sosiolog Modern. Jakarta: Kencana.

Soerjono Soekanto. 1984. Teori Sosiologi Tentang Pribadi dalam Masyarakat. Jakarta: Ghalia Indonesia.

1983. Kamus Sosiologi. Jakarta: Rajawali.

------. 2003. Sosiologi Suatu Pengantar. Jakarta: RajaGrafindo Persada.
Soeparmo. 1983. Catatan Sejarah 700 Tahun Tuban. Tuban: Kantor Informasi dan Komunikasi.

Soetomo. 2008. Masalah Sosial dan Upaya Pemecahannya. Yogyakarta: Pustaka Pelajar.

Soleman B Taneko. 1984. Struktur dan Proses Sosial Suatu Pengantar Sosiologi Pembangunan. Jakarta: Rajawali.

Sugiyono. 2008. Metode Penelitian Kuantitatif, Kualitatif dan $R \in \mathcal{E} D$. Bandung: Alfabeta.

Sumandiyo Hadi. 2007. Sosiologi Tari. Yogyakarta: Pustaka.

Sunyoto Usman. 2004. Sosiologi Sejarah Teori dan Metodologi. Yogyakarta: Cired.

St Vembriarto. 1984. Pathologi Sosial. Yogyakarta: Andi Offset.

W J S Poerwadarminta. 2s005. Kamus Umum Bahasa Indonesia. Jakarta: Balai Pustaka.

Agustiwati. 2007. Motivasi dan Keterlibatan Penonton dalam Pertunjukan Tayub di Desa Tunggak, Kecamatan Toroh, Kabupaten Grobogan. Semarang: UNNES.

Setyo Edy Pranoto. 2009. Persepsi Masyarakat Terhadap Terkikisnya Seni tari Dolalak di Kelurahan Cangkrep Lor Kecamatan Purworejo Kabupaten Purworejo. Yogyakarta: UNY.

Didiek. 1988. Ledhek Tayuban Isih 
| Fenomena Tari Tayub

Akeh Sing Geleman. Mekar Sari. Triyuana Agatha. 1989. Tayub. Jaya hlm. 26-27. Baya. hlm. 21-22 dan 49.

Bambang. 1991. Menghilangkan Sas. 1989. Tayub Mlebu Hotel. No.

Kesan Mesum dalam Seni Tayub. 42. Panjebar Semangat. hlm. 19 dan Suara Merdeka. hlm.11. 34. 
| Arim Syahroni

DIMENSIA, Volume 6, No. 1, Maret 2012 | 34 